\title{
PROGRAM KOMPUTER UNTUK MENGHITUNG AKTIVITAS CUPLIKAN SISTEM PENCACAH KAMAR PENGION MERLIN GERIN
}

\author{
Prajitno \\ Puslitbang Teknologi Maju-BATAN \\ Jl. Babarsari Kotak Pos 6101 ykbb, Yogyakarta 55281
}

\begin{abstract}
ABSTRAK
PROGRAM KOMPUTER UNTUK MENGHITUNG AKTIVITAS CUPLIKAN SISTEM PENCACAH KAMAR PENGION MERLIN GERIN. Telah disusun suatu program komputer untuk perhitungan aktivitas cuplikan sistem pencacah kamar pengion. Sistem pencacah kamar pengion Merlin Gerin yang digunakan laboratorium standardisasi bidang metrologi radiasi P3KRBiN-BATAN, merupakan salah satu jenis peralatan ukur radiasi untuk pengukuran aktivitas berbagai macam radio nuklida. Untuk menampilkan data hasil pengukuran peralatan tersebut digunakan tampilan digital, tetapi pengambilan data hasil pengukurannya masih dilakukan secara manual sehingga ketelitian data yang diperoleh sangat bergantung pada operatornya. Untuk meningkatkan kinerja sistem, telah dilakukan penambahan perangkat keras berupa komputer personal dan multimeter digital serta analisis, perancangan dan pembuatan program komputer. Komputer berfungsi pengambil data secara otomatis berdasarkan runtutan perintah yang diberikan dan dilanjutkan dengan melakukan perhitungan menggunakan persamaan-persamaan yang telah ditentukan dan yang terakhir melakukan pencetakan hasil. Program komputer dibuat menggunakan bahasa pemrograman Delphi dan telah diuji coba langsung pada sistem. Perbandingan antara perhitungan oleh komputer dan perhitungan secara manual diperoleh hasil yang sama, sehingga dapat disimpulkan bahwa program komputer telah berfungsi sesuai dengan yang diharapkan dan unjuk kerja dari sistem pencacah telah dapat ditingkatkan.
\end{abstract}

\section{ABSTRACT}

COMPUTER PROGRAM TO CALCULATE THE ACTIVITY OF SAMPLE OF THE MERLIN GERIN IONIZATION CHAMBER COUNTING SYSTEM. A computer program for calculation of sample activity of ionization chamber counting system have been made. The measurement system of Merlin Gerin ionization chamber used by standardize laboratory of BATAN, representing one of equipments type that measure the radiation for the measurement of assorted activity of radio nuclide. To present the data result of the equipments measurement have used the digital appearance, but data intake result of its measurement still done in manual so that data correctness obtained depend on the operator. To increase system performance, the additional hardware in the form of personal computer and Digital Multimeter and also a software of computer program have been made. Computer function to do the data acquisition automatically pursuant to command given and continued by doing calculation use the equation which have been determined and to print of the result. Computer program have been made using Delphi programming language and tested directly to the system. Result of comparison between calculation by computer and manually calculation obtained the same result, so that can be concluded that computer program have perfectly functioned and matching with the one which expected and performance from measuring system improved.

\section{PENDAHULUAN}

Derkembangan dunia komputer saat ini telah semakin canggih, baik dari segi perangkat keras maupun perangkat lunak. Demikian pula dengan perkembangan peralatan elektronik khususnya peralatan yang digunakan di laboratorium maupun alat-alat ukur untuk menentukan besaran misalnya untuk mengukur tegangan, resistansi dan lain-lain, banyak yang sudah mempunyai fasilitas keluaran yang dapat dikomunikasikan dengan komputer lewat komunikasi seri atau paralel.

Sistem pengukuran kamar pengion Merlin Gerin merupakan salah satu jenis peralatan ukur radiasi untuk menentukan aktivitas berbagai macam radio nuklida. Sistem ini memiliki peranan sangat penting di laboratorium standardisasi bidang metrologi radiasi di Puslitbang Keselamatan Radiasi dan Biomedika Nuklir BATAN. Data hasil pengukuran peralatan tersebut adalah tegangan DC dan ditampilkan dalam bentuk digital. Pengambilan dan pemrosesan data hasil pengukuran masih dilakukan secara manual, dengan cara petugas mencatat data yang tertampil yaitu: latar (back-ground), cuplikan (sample) dan standar masing-masing sebanyak 60 kali, oleh karena itu ketelitian data yang diperoleh sangat bergantung pada kondisi petugas yang melakukan 
pengukuran ${ }^{[1]}$. Data hasil pengukuran tersebut selanjutnya dihitung untuk mendapatkan : rata-rata hasil pengukuran, deviasi standar, ketidakpastian, faktor cakupan data pengukuran dan akhirnya akan diperoleh hasil berupa informasi aktivitas cuplikan. Aktivitas cuplikan dapat diketahui apabila cuplikan yang diukur dan standar radionuklida yang digunakan sama.

Untuk meningkatkan unjuk kerja sistem pencacah telah ditambahkan satu unit komputer dan peralatan antarmuka untuk mengukur tegangan DC hasil pengukuran aktivitas radio nuklida yaitu berupa Multi Meter Digital (MMD) yang memiliki keluaran RS-232 $2^{[2]}$, dengan menggunakan MMD ini data hasil pengukuran dapat diakses komputer.

Tujuan penelitian ini adalah melakukan analisis kebutuhan dan membuat program komputer yang dapat berfungsi untuk mengambil data yang diukur oleh MMD dan menghitung aktivitas cuplikan.

Untuk menggambarkan algoritma digunakan pseudocode sesuai dengan bahasa yang digunakan pemrogram ${ }^{[3]}$, sedangkan bahasa pemrograman yang digunakan adalah Delphi Versi 5.0.

Semua data hasil pengukuran dan hasil perhitungan serta informasi lain yang diperlukan disimpan dalam komputer dan selanjutnya dapat juga dicetak untuk dijadikan laporan hasil pengukuran cuplikan.

\section{TATA KERJA}

Blok diagram sistem pencacah kamar pengion Merlin Gerin seperti terlihat pada Gambar 1. Apabila detektor Merlin Gerin diberi catu tegangan tinggi, saat ada radio nuklida di depan detektor maka penguat awal akan mengeluarkan arus yang besarnya sebanding dengan aktivitas radio nuklida. Keluaran arus dari penguat awal selanjutnya dimasukkan ke Elektrometer dan agar masukan arus dapat terbaca, operator harus mengatur switch kepekaan/jangkauan $\left(10^{-13}, 10^{-12}, 10^{-11}\right)$. Selain tertampil dalam bentuk digital, Elektrometer juga menyediakan keluaran tegangan yang sesuai tampilan.

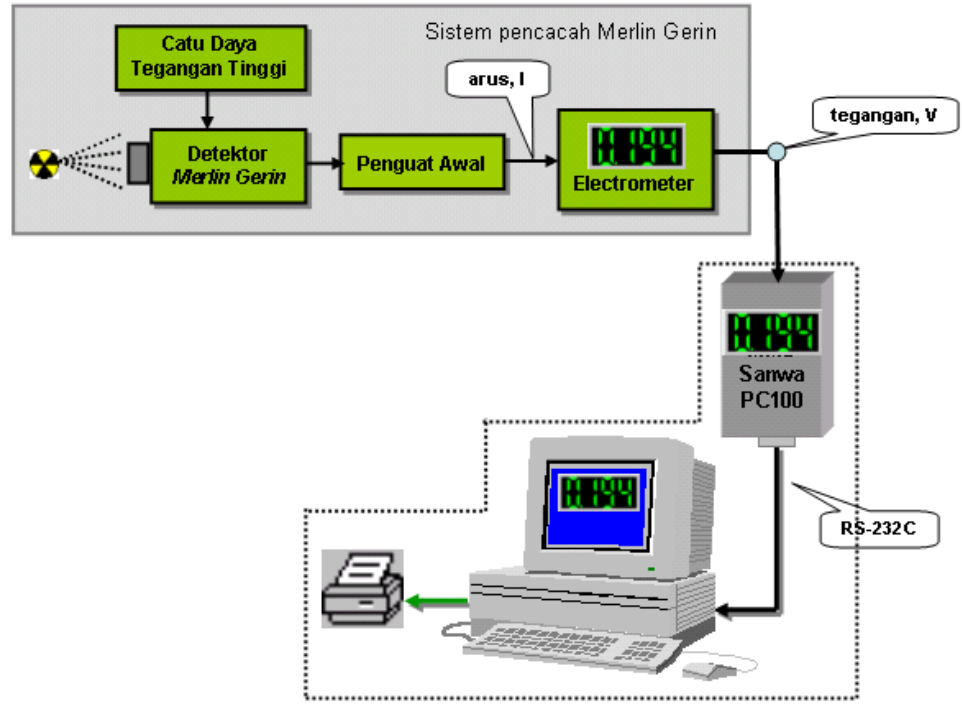

Gambar 1. Blok diagram sistem pencacah kamar pengion Merlin Gerin.

Bagian yang dibatasi garis putus pada Gambar 1 adalah bagian yang ditambahkan pada sistem dengan tujuan agar data keluaran tegangan elektrometer dapat diakses komputer lewat perantara MMD Sanwa PC-100.

\section{Multimeter Digital (MMD) SANWA PC-100}

Multimeter Digital SANWA PC100 adalah alat ukur besaran fisis yang mempunyai keluaran RS-232C, secara periodik mengeluarkan data sesuai dengan yang tertampil pada layar MMD. Data yang dikirimkan MMD dalam bentuk ASCII panjang 13 karakter, dengan format data seperti contoh berikut:

$$
\begin{aligned}
\text { DCV },-2.361 \mathrm{E}-1 & =\text { Tegangan } \mathrm{DC},-2,361 \times 10^{-1} \\
& =-0,2361 \text { volt } \\
\mathrm{DCV},-2.015 \mathrm{E}+0 & =\text { Tegangan } \mathrm{DC},-2,015 \times 10^{0} \\
& =-2,015 \text { volt }
\end{aligned}
$$


$\mathrm{DCV}, 1.577 \mathrm{E}+0=$ Tegangan DC, $1,577 \times 10^{\circ}$

$=1,577$ Volt

Keluaran port RS-232-C MMD dihubungkan ke Com-X personal komputer, data hasil pengukuran tersebut setelah diukur oleh komputer akan dikonversi dari runtunan string ASCII menjadi bilangan real sehingga selanjutnya dapat dilakukan perhitungan untuk menentukan aktivitas cuplikan dengan menggunakan persamaan seperti Lampiran 1.

\section{Pcomm}

Pustaka PCOMM adalah tool yang berisi modul-modul program komputer yang digunakan untuk pengembangan perangkat lunak yang mudah diimplementasikan dalam komunikasi data serial menggunakan bahasa pemrograman Delphi. Modul-modul program tersebut adalah:

$\begin{array}{ll}\text { sio_open } & \text { Mulai untuk menerima/ mengirim data } \\ \text { sio_close } & \text { Hentikan menerima/ mengirim data } \\ \text { sio_ioctl } & \text { Mengartur port baud rate, parity dsb. } \\ \text { sio_flowctrl } & \text { Mengatur kontrol aliran Perangkat Keras dan atau Perangkat Lunak } \\ \text { sio_flush } & \text { Flush input and/or output buffer } \\ \text { sio_getbaud } & \text { Mendapatkan pengaturan baud rate } \\ \text { sio_read } & \text { Baca suatu blok data dari penyangga driver input } \\ \text { sio_AbortRead } & \text { Menggagalkan saat membaca blok data untuk sio_read() } \\ \text { sio_DTR } & \text { Atur DTR state } \\ \text { sio_RTS } & \text { Atur RTS state }\end{array}$

Kecepatan pengambilan data oleh komputer diatur menyesuaikan pengaturan DMM yang dilakukan oleh pabrik pembuat, yaitu:

Baud Rate : : B9600

Parity $\quad:=$ P_NONE

Byte Size : : BIT_8

Stop Bits : : STOP_1

\section{Pseudocode}

Pseudocode adalah salah satu cara untuk menggambarkan algoritma dengan menggunakan bahasa sesuai yang digunakan oleh pembuat program komputer. Untuk memberikan gambaran program komputer yang dibuat, dituliskan pseudocode seperti runtunan berikut:

Masukkan data petugas dan lingkungan alat

Masukkan data sumber standar

Hitung waktu peluruhan sumber standar

Hitung aktivitas sumber standar

Set $n$ jadi 1 ( $n=1=$ latar, $n=2=$ sampel $n=3=$ standar)

ULANG

Set $m$ jadi 1

ULANG

Baca data ke[m] dari multi meter digital

Simpan data ke[n,m] dalam memori komputer

$m=m+1$

SAMPAI $m=60$

Hitung rata-rata data[n,1..60]

Hitung standar deviasi

Hitung ketidakpastian

Masukkan faktor perkalian jangkauan ukur

$n=n+1$

SAMPAI $n=3$ 
Hitung aktivitas cuplikan

Hitung ketidakpastian gabungan

Simpan semua data dan hasil perhitungan

Tampilkan data dan hasil perhitungan

\section{HASIL DAN PEMBAHASAN}

Gambar 2 adalah tampilan awal dari hasil program, tanda 1 adalah keterangan yang harus diisi oleh operator sebelum dapat melanjutkan mengisi data sumber standar (tanda 2). Tanda 3 adalah jendela untuk menampilkan data yang diterima dari MMD dan tanda 4 jendela untuk menampilkan banyaknya data, jangkauan untuk tampilan ini adalah dari 1 sampai 60 sesuai dengan jumlah data yang diambil untuk diproses. Sedangkan tanda 5, 6 dan 7 adalah untuk menampilkan data hasil pengukuran arus/tegangan latar, arus/tegangan cuplikan dan arus/tegangan standar. Tanda 8 adalah kelompok tombol untuk memilih urutan pengambilan data yang dimulai data latar, data cuplikan dan data standar. Tanda 9 merupakan pilihan untuk menyimpan semua data termasuk data hasil perhitungan, melihat hasil di layar monitor dan pilihan cetakan printer. Sedangkan tanda 10 adalah tombol untuk menampilkan informasi tentang perangkat lunak yang dibuat.

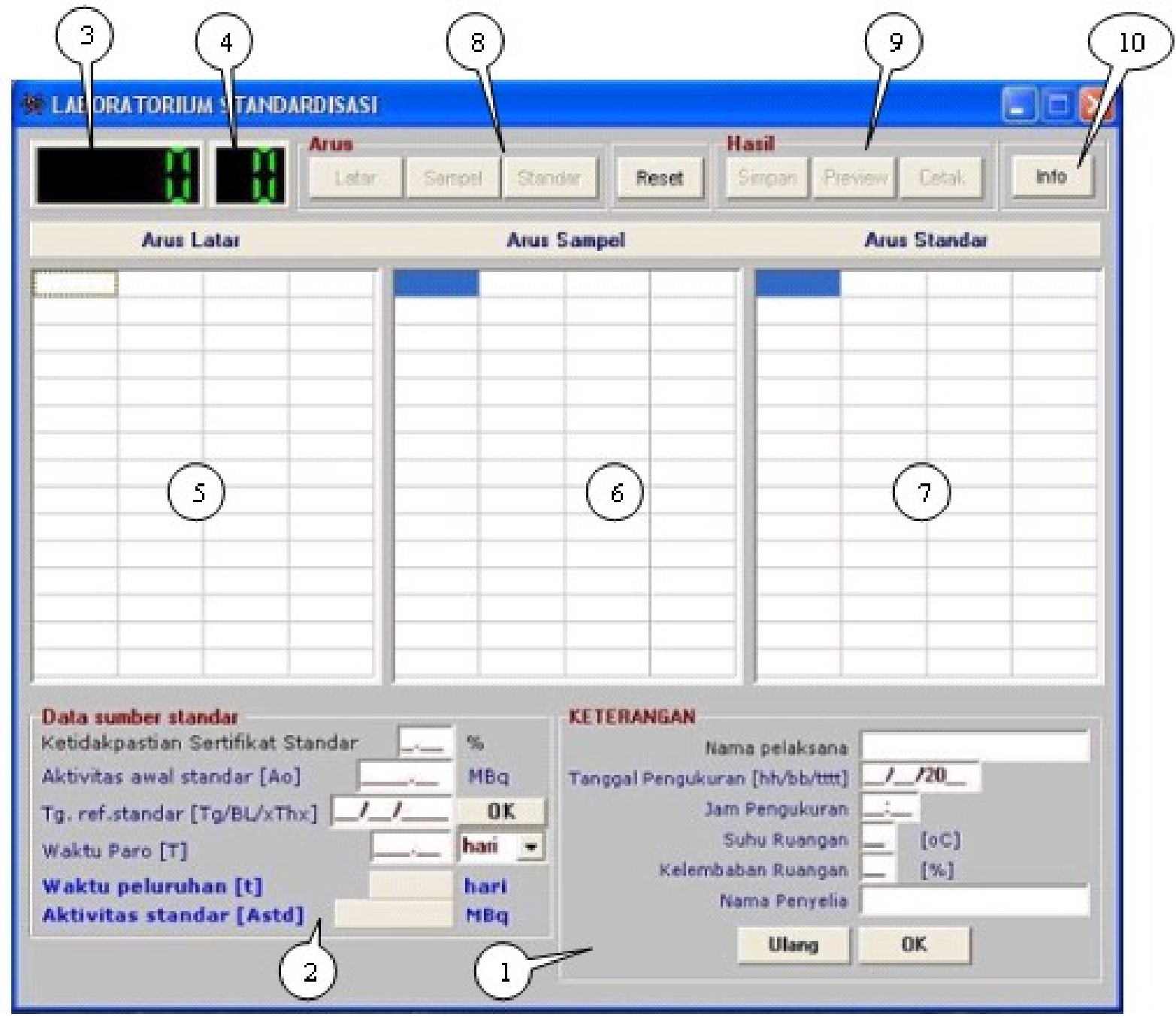

Gambar 2. Hasil tampilan awal 


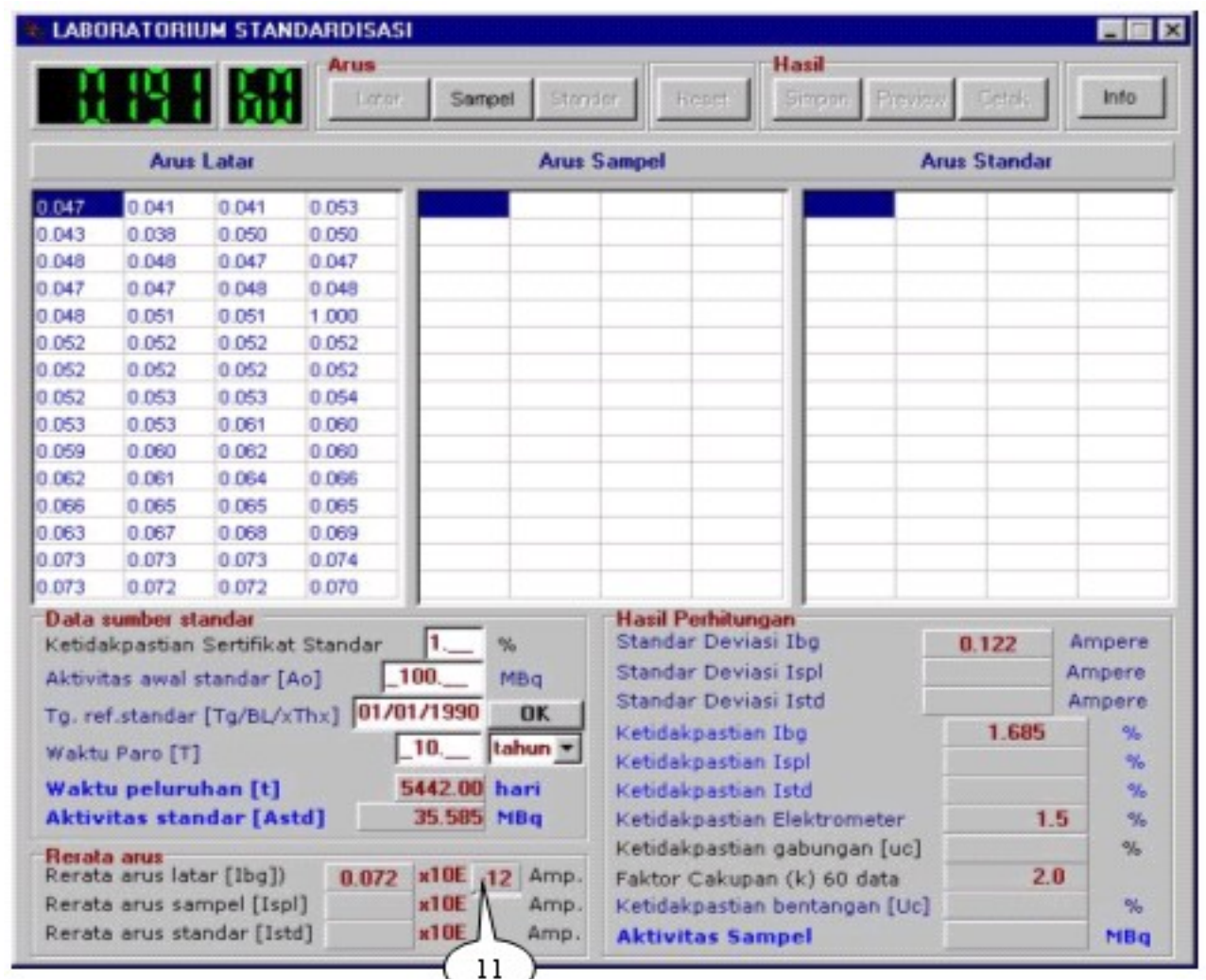

Gambar 3. Tampilan hasil setelah pengukuran latar

\begin{tabular}{|c|c|c|c|c|c|c|c|c|c|c|c|c|c|}
\hline \multicolumn{13}{|c|}{ LABORATORIUM STANDARDISASI } & $-\square[$ \\
\hline & & & \multicolumn{6}{|c|}{ Arus } & \multicolumn{4}{|c|}{ Hasil } & \multirow[b]{2}{*}{ Info } \\
\hline & & & & Latar & Sam & mpel & Star & & Reset & Simpan & Previews & Cetak. & \\
\hline \multicolumn{5}{|c|}{ Arus Latar } & \multicolumn{5}{|c|}{ Arus Sampel } & \multicolumn{4}{|c|}{ Arus Standar } \\
\hline 0.047 & 0.041 & 0.041 & \multicolumn{2}{|c|}{0.053} & 0.030 & & 0.030 & 0.030 & 0.030 & 0.001 & 0.006 & 0.007 & 0.011 \\
\hline 0.043 & 0.038 & 0.050 & \multicolumn{2}{|c|}{0.050} & 0.025 & & 0.026 & 0.026 & 0.024 & 0.011 & 0.012 & 0.012 & 0.013 \\
\hline 0.048 & 0.048 & 0.047 & \multicolumn{2}{|c|}{0.047} & 0.023 & & 0.023 & 0.019 & 0.020 & 0.014 & 0.014 & 0.015 & 0.015 \\
\hline 0.047 & 0.047 & 0.048 & \multicolumn{2}{|c|}{0.048} & 0.022 & & 0.022 & 0.021 & 0.022 & 0.016 & 0.016 & 0.017 & 0.021 \\
\hline 0.048 & 0.051 & 0.051 & \multicolumn{2}{|c|}{1.000} & 0.022 & & 0.021 & 0.021 & 0.020 & 0.019 & 0.020 & 0.022 & 0.023 \\
\hline 0.052 & 0.052 & 0.052 & \multicolumn{2}{|c|}{0.052} & 0.020 & & 0.020 & 0.018 & 0.017 & 0.023 & 0.023 & 0.023 & 0.021 \\
\hline 0.052 & 0.052 & 0.052 & \multicolumn{2}{|c|}{0.052} & 0.016 & & 0.016 & 0.017 & 0.013 & 0.015 & 0.018 & 0.017 & 0.020 \\
\hline 0.052 & 0.053 & 0.053 & \multicolumn{2}{|c|}{0.054} & 0.012 & & 0.012 & 0.012 & 0.013 & 0.024 & 0.025 & 0.026 & 0.027 \\
\hline 0.053 & 0.053 & 0.061 & \multicolumn{2}{|c|}{0.060} & 0.013 & & 0.013 & 0.007 & 0.006 & 0.027 & 0.027 & 0.027 & 0.031 \\
\hline 0.059 & 0.060 & 0.062 & 0.0 & 60 & 0.005 & & 0.006 & 0.002 & 0.003 & 0.030 & 0.029 & 0.029 & 0.029 \\
\hline 0.062 & 0.061 & 0.064 & 0.0 & 66 & 0.009 & & 0.009 & 0.007 & 0.005 & 0.031 & 0.032 & 0.032 & 0.034 \\
\hline 0.066 & 0.065 & 0.065 & 0.0 & 65 & 0.001 & & 0.001 & 0.002 & 0.002 & 0.036 & 0.036 & 0.035 & 0.035 \\
\hline 0.063 & 0.067 & 0.068 & 0.0 & 669 & 0.003 & & 0.002 & 0.003 & 0.003 & 0.035 & 0.037 & 0.036 & 0.037 \\
\hline 0.073 & 0.073 & 0.073 & 0.0 & 974 & 0.000 & & 0.001 & 0.004 & 0.002 & 0.037 & 0.037 & 0.036 & 0.035 \\
\hline 0.073 & 0.072 & 0.072 & 0.0 & 970 & 0.001 & & 0.000 & 0.003 & 0.002 & 0.035 & 0.035 & 0.035 & 1.000 \\
\hline Data & Imber s & ndar - & & & & & & Hasi & erhitur & & & & \\
\hline Ketid & pastiar & Sertifika & $=$ & indar & 1. & $\%$ & & & ar Devi & & & 0.122 & Ampere \\
\hline Aktiv & s awal & andar [ & & & 100. & ME & $\mathrm{Bq}$ & Stan & dar Devi & i Ispl & & 0.010 & Ampere \\
\hline $\mathrm{Tg}, \mathrm{r}$ & standa & $\mathrm{Tg} / \mathrm{BL} /$ & 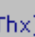 & 0 & $\overline{11 / 1990}$ & & OK & Stan & dar Devi & si Istd & & 0.126 & Ampere \\
\hline & status & & & & & & & Ketid & dakpastia & Ibg & & 1.685 & $\%$ \\
\hline Wakt & Paro $[T$ & & & & $-^{10}$. & |tah & - & Ketid & Jakpastia & Ispl & & 0.733 & $\%$ \\
\hline Wak & pelur & $\operatorname{an}[t]$ & & & 5442.00 & ha & & Ketic & Jakpastia & Istd & & 3.103 & $\%$ \\
\hline Akti & tas sta & $\operatorname{dar}[\mathrm{A}$ & & & 35.585 & $5 \mathrm{ME}$ & & Ketid & dakpastia & Elektrome & ter & 1. & $\%$ \\
\hline Reral & rus - & & & & & & & Ketic & Jakpastia & gabungan & [uc] & 4.03178 & $\%$ \\
\hline Rerat & 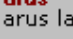 & $r[\mathrm{Ibg}])$ & & 0.072 & $\mathbf{x} 10 \mathrm{E}$ & -12 & Amp. & Fakt & or Cakup & $n(k) 60 d$ & & 2.0 & \\
\hline Rerat & arus si & pel [Is & & 0.013 & $\mathbf{x} 10 \mathrm{E}$ & -11 & Amp. & Ketid & Jakpastia & bentanga & [Uc] & 8.06356 & $\%$ \\
\hline Rerat & arus st & dar [Is & & 0.041 & $x 10 E$ & -10 & Amp. & & & & & 0.50889 & MBq \\
\hline
\end{tabular}

Gambar 4. Tampilan hasil akhir setelah pengukuran latar, cuplikan dan standar 
Tanda 11 pada Gambar 3 adalah isian yang harus diisi oleh operator sesuai dengan posisi switch kepekaan pengukuran pada alat elektrometer.

Waktu peluruhan $(t)$ ditentukan dengan menghitung selisih banyaknya hari antara tanggal referensi standar dan tanggal saat pengukuran dilakukan, sedangkan perhitungan lainnya menggunakan persamaanpersamaan yang ada pada Lampiran 1 yaitu: Rerata arus dihitung menggunakan persamaan 1, Standar deviasi dengan persamaan 2, Ketidakpastian dengan persamaan 3, Ketidakpastian gabungan dengan persamaan 4 , Ketidakpastian bentangan dengan persamaan 5 , Aktivitas standar dihitung dengan persamaan 6 , sedangkan aktivitas cuplikan dihitung dengan persamaan 7 .

Pada Gambar 4 diberikan contoh rerata-arus untuk latar, cuplikan dan standar mempunyai faktor perkalian yang berbeda yaitu $10^{-12}, 10^{-11}$ dan $10^{-10}$.

Untuk memudahkan perhitungan dalam menentukan ketidakpastian gabungan, faktor perkalian dibuat sama dengan pseudocode sebagai berikut:

JIKA pangkat_latar > pangkat_cuplikan

$\mathrm{N}:=$ absolut(pangkat_latar) - absolut

(pangkat_cuplikan)

Set pangkat jadi 0

ULANG

rerata_latar:=rerata_latar ${ }^{*} 10$

pangkat:=pangkat +1

SAMPAI pangkat $=\mathrm{N}$

SELAINNYA JIKA pangkat_latar > pangkat_standar

$\mathrm{N}:=$ absolut(pangkat_latar) - absolut

(pangkat_standar)

Set pangkat jadi 0

ULANG

rerata_standar:=rerata_standar ${ }^{*} 10$

pangkat:=pangkat +1

SAMPAI pangkat $=\mathrm{N}$

AKHIR JIKA;

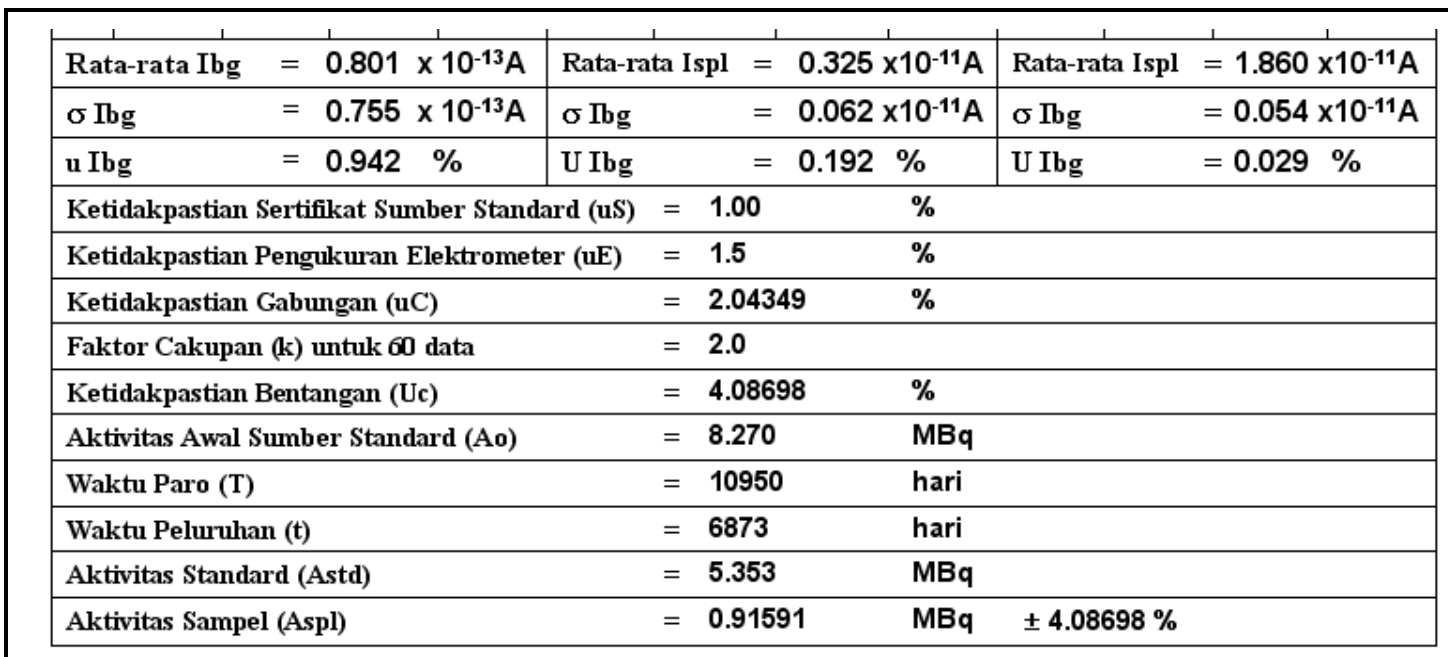

Gambar 5. Hasil perhitungan program komputer 


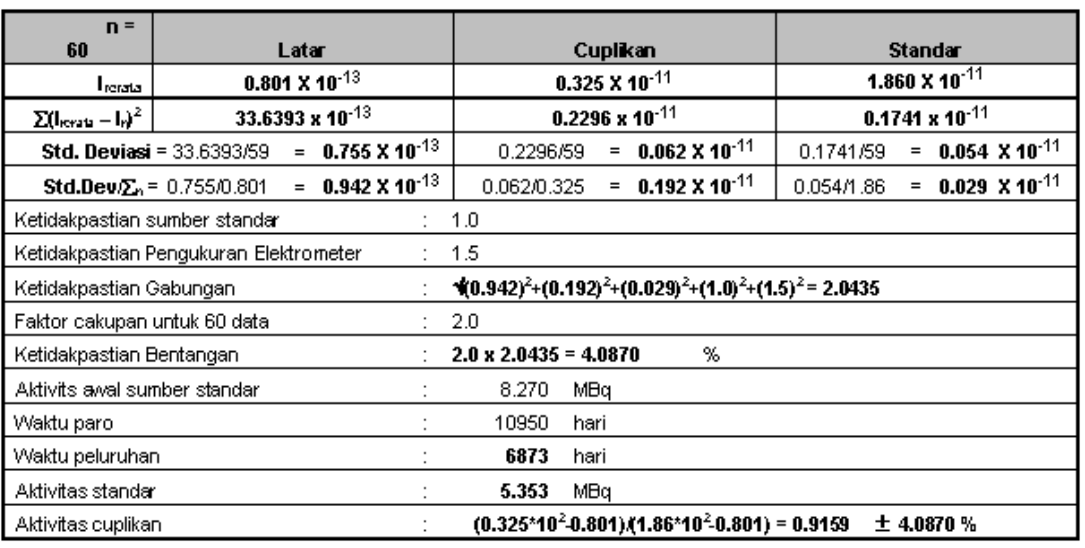

Gambar 6. Hasil perhitungan secara manual

Pada Lampiran 2 diberikan hasil akhir program komputer dalam bentuk cetakan, hasil pengujian program komputer ini menggunakan sumber/cuplikan Cs-137 dengan ketidakpastian sertifikat 1\%. Untuk menguji kebenaran hasil program komputer, telah dilakukan perhitungan secara manual dengan data yang sama dan diperoleh hasil seperti pada Lampiran 3.

Apabila dibandingkan antara perhitungan komputer dan perhitungan manual, terdapat tiga item yang sedikit berbeda yaitu: Ketidakpastian Gabungan, Ketidakpastian Bentangan dan Aktivitas Cuplikan, selisihnya adalah:

Selisih Ketidakpastian Gabungan $=2.0435-2.04349=0.00001$

Selisih Ketidakpastian Bentangan $=4.0870-4.08698=0.00002$

Selisih Aktivitas Cuplikan $\quad=0.9159-0.91591=0.00001$

Selisih tersebut terjadi karena dalam perhitungan manual terjadi pemenggalan/pembulatan digit dibelakang koma.

\section{KESIMPULAN}

Dari hasil pengujian program komputer dapat disimpulkan bahwa:

- Perhitungan aktivitas cuplikan radionuklida yang dihitung oleh program komputer sudah dapat berfungsi seperti yang diharapkan dan bila dibandingkan dengan perhitungan yang dilakukan secara manual ada perbedaan sedikit dimana sedikit perbedaan yang ada karena pembulatan digit dibelakang koma.

- Unjuk kerja sistem sudah dapat ditingkatkan karena semua perhitungan untuk menentukan aktivitas cuplikan radionuklida sudah dilakukan komputer.

- Hasil perhitungan aktivitas cuplikan dapat dicetak ulang karena semua datanya disimpan sesuai dengan jam dan tanggal saat perhitungan dilakukan

\section{UCAPAN TERIMA KASIH}

Penulis mengucapkan terima kasih kepada Sdr. Wijono, ST dan Dra. Nazaroh atas bantuannya menguji program komputer dan masukan-masukan sehingga program komputer ini dapat terwujud.

\section{DAFTAR PUSTAKA}

1. Perhitungan Ketidakpastian Kemampuan Ukur Terbaik, Lab. Metrologi Radiasi P3KRBiN-BATAN, No. Dokumen: IK-LMR-STD-11, Rev.0, 2002.

2. Instruction Manual DMM PC100, Sanwa Electric Instrument Co. Ltd., 2002

3. GUY J. HALE, RICHARD J. EASTON, Applied Data Structure Using Pascal, D.C Heath and Company, Canada, 1987.

4. The NIST Reference on Constants, Units and Uncertainty, Expanded uncertainty and coverage factor, http:/physics.nist.gov/uncertainty (2004). 


\section{Lampiran 1}

Perhitungan aktivitas cuplikan (sumber standar = cuplikan)

Rerata arus

$$
\bar{I}=\frac{\sum n}{n}
$$

Sehingga diperoleh nilai deviasi standar

$$
\sigma I=\sqrt{\frac{\sum\left(\bar{I}-I_{i}\right)^{2}}{n-1}}
$$

Ketidakpastian

$$
u=\frac{\sigma I}{\bar{I}}
$$

Ketidakpastian gabungan

$$
u_{c}=\sqrt{\left\{\left(\sum u \bar{I}_{i}\right)^{2}+(u S)^{2}+(u E)^{2}\right\}}
$$

(uS) Ketidakpastian sertifikat sumber standar

$(u E)$ Ketidakpastian pengukuran alat ukur

Ketidakpastian bentangan

Aktivitas cuplikan radionuklida

$$
U_{c}=k \cdot u_{c}
$$

$$
A_{S P L}=\frac{I_{S P L}-I_{B G}}{I_{S T D}-I_{B G}} \cdot A_{S T D}
$$

Cuplikan radionuklida

$$
A_{S M P}=A_{S P L} \pm U_{c}
$$

Sumber standar

$$
A_{S T D}=A_{0} \cdot e^{-\frac{\ln 2}{T 1 / 2} \cdot t}
$$
$\left(A_{0}\right)$ aktivitas awal,
$\left(T_{1 / 2}\right)$ waktu paro,
(t) waktu peluruhaan.

Tabel 1. Hubungan derajat kebebasan terhadap faktor cakupan

\begin{tabular}{|c|c|c|c|c|c|c|c|}
\hline $\begin{array}{c}\text { Derajat } \\
\text { Kebebasan }\end{array}$ & $\begin{array}{c}\text { Nilai } \mathbf{k} \\
\text { pada TK } \\
\mathbf{9 5 \%}\end{array}$ & $\begin{array}{c}\text { Derajat } \\
\text { Kebebasan }\end{array}$ & $\begin{array}{c}\text { Nilai } \mathbf{k} \\
\text { pada TK } \\
\mathbf{9 5 \%}\end{array}$ & $\begin{array}{c}\text { Derajat } \\
\text { Kebebasan }\end{array}$ & $\begin{array}{c}\text { Nilai } \mathbf{k} \\
\text { pada TK } \\
\mathbf{9 5 \%}\end{array}$ & $\begin{array}{c}\text { Derajat } \\
\text { Kebebasan }\end{array}$ & $\begin{array}{c}\text { Nilai } \mathbf{k} \\
\text { pada TK } \\
\mathbf{9 5 \%}\end{array}$ \\
\hline 1 & 12.706 & 7 & 2.365 & 13 & 2.160 & 19 & 2.093 \\
\hline 2 & 4.303 & 8 & 2.306 & 14 & 2.145 & 20 & 2.086 \\
\hline 3 & 3.182 & 9 & 2.262 & 15 & 2.131 & 25 & 2.060 \\
\hline 4 & 2.776 & 10 & 2.228 & 16 & 2.120 & 30 & 2.042 \\
\hline 5 & 2.571 & 11 & 2.201 & 17 & 2.110 & 60 & 2 \\
\hline 6 & 2.447 & 12 & 2.179 & 18 & 2.101 & $>>60$ & 1.96 \\
\hline
\end{tabular}




\section{Lampiran 2}

\begin{tabular}{|c|c|c|c|c|}
\hline \multirow{5}{*}{ 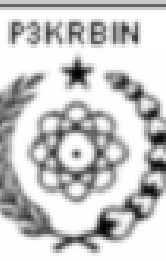 } & SISTE & \multicolumn{2}{|c|}{ LABORATORIUM STANDARDISASI } & GERIN \\
\hline & Pelakssana & Wipno & Paraf & 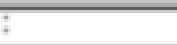 \\
\hline & Tanggal Pengukuran & $27 / 70 / 2003$ & Jam Pengukuran & $12.15 \mathrm{WIB}$ \\
\hline & Temperatur & $25^{\circ} \mathrm{C}$ & Kelembaban & $65 \%$ \\
\hline & Penyelia & Ermi & Paraf & 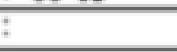 \\
\hline BRTAN & Pengesahan & : & Paraf & 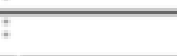 \\
\hline
\end{tabular}

DATA CACAHAN SAMPEL $=$ SUMBER STANDARD

\begin{tabular}{|c|c|c|c|c|c|c|c|c|c|c|c|c|}
\hline \multirow{2}{*}{$\frac{100}{1}$} & \multicolumn{4}{|c|}{$\begin{array}{l}\text { Arus Latar (lbo) } \\
\text { (Ampere) }\end{array}$} & \multicolumn{4}{|c|}{$\begin{array}{l}\text { Arus Sampel (isp) } \\
\text { (Ampere) }\end{array}$} & \multicolumn{4}{|c|}{$\begin{array}{l}\text { Prus Standard (istd) } \\
\text { (Ampere) }\end{array}$} \\
\hline & 0.593 & 3. 149 & 3.839 & 0.597 & 0.319 & \begin{tabular}{|l|}
0.356 \\
\end{tabular} & 0.214 & 6.449 & 1.890 & 1.793 & 1.826 & 1.820 \\
\hline 2 & 0. 127 & 0.271 & 0.848 & 0.655 & 0.232 & 0.372 & 0.347 & 0.224 & 1.926 & 1.872 & 1.895 & 1.852 \\
\hline 3 & 0.473 & 0.219 & 6.582 & 0.996 & 0.329 & 0.432 & 0.279 & 0.268 & 1.836 & 1821 & 1.861 & 1.815 \\
\hline 4 & 0.517 & 0.430 & 0.915 & 0.45 & 0.359 & 0.335 & 0.250 & 0.318 & 1.908 & 1.781 & L.901 & 1.910 \\
\hline 5 & 0.506 & 9. 113 & 0.240 & 0. 152 & 0.247 & 0.367 & 0.333 & 0.339 & 1.768 & 1.965 & 1.913 & 1.905 \\
\hline 6 & 3.043 & 0.871 & 6.907 & 0.272 & 0.361 & 0.287 & 0.368 & 0.375 & 1.878 & 1.822 & 1.864 & 1.843 \\
\hline 7 & 0.479 & 2. 395 & e. 117 & 0. 104 & 0.369 & 0.267 & 0.397 & 0.305 & 1.903 & 1.639 & 1.932 & 1.831 \\
\hline 8 & 0.386 & 0. 300 & -0.202 & 0.603 & 0.284 & 0.375 & 0.308 & 0.372 & 1.770 & 1.854 & 1.956 & 1.780 \\
\hline 9 & 2.415 & 0.251 & 6.759 & 0.453 & 0.349 & 0.221 & 0.386 & 0.369 & 1.890 & 1.856 & 1.892 & 1.907 \\
\hline 10 & 6. 197 & 0.795 & 0.666 & 0.206 & 0. 300 & 0.274 & 0.267 & 0.322 & 1.827 & 1.887 & 1.850 & 1.863 \\
\hline 11 & 0.950 & 1.272 & 6.988 & 0.606 & 0.233 & 0.381 & 0.552 & 0.296 & 1.847 & 1.840 & 1.863 & 1.855 \\
\hline 12 & 0. 183 & 0.718 & 1.684 & 0.765 & 0.379 & 0.220 & 0.338 & 0.311 & 1.854 & 1.865 & 1.891 & 1.864 \\
\hline B & 0.665 & 6. 551 & 1.672 & 1.325 & 0.287 & 0.311 & 0.274 & 0.276 & 1.975 & 1.871 & 1.821 & 1.760 \\
\hline 14 & 1.271 & 1.232 & 0.747 & 0.754 & 0.398 & 0.346 & 0.379 & 0.334 & 1.884 & 1.863 & 1.854 & 1.857 \\
\hline 15 & 0.961 & 0.804 & 0.918 & 0.424 & 0.311 & 0.291 & 0.371 & 0.280 & 1.883 & 1.881 & 1.822 & 1.895 \\
\hline \multicolumn{5}{|c|}{ Ruta-rah Dg } & \multicolumn{4}{|c|}{ Ratarah Lql $=0325 \times 10^{-11} \mathrm{~A}$} & \multicolumn{4}{|c|}{ Ruta-rah Iql $=1860 \times 10^{-11} \mathrm{~A}$} \\
\hline \multicolumn{2}{|c|}{$\boldsymbol{\sigma} \mathbf{D g}$} & $=$ & 55 & $b^{-1-A}$ & - DE & $=$ & 0.062 & 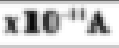 & \multicolumn{4}{|c|}{ EDE $=0.054 \times 10^{-11} \mathrm{~A}$} \\
\hline \multicolumn{2}{|c|}{ u DE } & $=$ & & $\%$ & $\mathbf{U} \mathbf{D g}$ & $=$ & 0192 & $\%$ & U D $\mathbf{g}$ & & 0.029 & $\%$ \\
\hline \multicolumn{6}{|c|}{ Ketilalquian Serifilkat Sunber Standurl (US) } & $=1.00$ & & \multicolumn{5}{|l|}{$\%$} \\
\hline \multicolumn{6}{|c|}{ Ketilalqusian Fengulorran Eeditruneter (4E) } & $=1.5$ & & \multicolumn{5}{|l|}{$\%$} \\
\hline \multicolumn{6}{|c|}{ Ketilalquorian Calumgan (uC') } & $=2.043$. & & \multicolumn{5}{|l|}{$4 / 6$} \\
\hline \multicolumn{6}{|c|}{ Falder Caloquan Q9untuk 60 data } & $=2.0$ & & \\
\hline \multicolumn{6}{|c|}{ Ketilalquatian Bentangan (Ue) } & $=4.086$ & & \multicolumn{5}{|l|}{$\%$} \\
\hline \multicolumn{6}{|c|}{ Alititas Avod Sunber Standard (A.) } & $=8.270$ & & \multicolumn{5}{|l|}{$\mathrm{MBq}$} \\
\hline \multicolumn{6}{|c|}{ Walda Fare (T) } & $=10950$ & & \multicolumn{5}{|l|}{ hari } \\
\hline \multicolumn{6}{|c|}{ Walin Fehmulhan (x) } & $=6873$ & & \multicolumn{5}{|l|}{ hari } \\
\hline \multicolumn{6}{|c|}{ Altinitus Standard (Aoti) } & 5.353 & & \multicolumn{5}{|l|}{$\mathrm{MBq}$} \\
\hline Al: & titas $5 \mathrm{a}$ & geas (As & & & & $=0.915$ & & $M B q$ & \pm 4.0 & $598 \%$ & & \\
\hline
\end{tabular}

Pemberi tugas

Manajer/Deputi Manajer Standardisasi 
Program Komputer Untuk Menghitung Aktivitas Cuplikan Sistem Pencacah Kamar Pengion Merlin Gerin

\section{Lampiran 3}

\begin{tabular}{|c|c|c|c|c|c|c|}
\hline $\mathrm{n}$ & Latar & $\left(I_{\text {rata-rata }}-I_{n}\right)^{2}$ & Cuplikan & $\left(I_{\text {rata-rata }}-I_{n}\right)^{2}$ & Standar & $\left(I_{\text {rata-rata }}-I_{n}\right)^{2}$ \\
\hline 1 & 0.593 & 0.0433 & 0.319 & 0.0000 & 1.890 & 0.0009 \\
\hline 2 & 0.177 & 0.3894 & 0.232 & 0.0086 & 1.926 & 0.0044 \\
\hline 3 & 0.473 & 0.1076 & 0.329 & 0.0000 & 1.836 & 0.0006 \\
\hline 4 & 0.517 & 0.0807 & 0.359 & 0.0012 & 1.908 & 0.0023 \\
\hline 5 & 0.506 & 0.0870 & 0.247 & 0.0061 & 1.768 & 0.0085 \\
\hline 6 & 3.043 & 5.0266 & 0.361 & 0.0013 & 1.878 & 0.0003 \\
\hline 7 & 0.479 & 0.1037 & 0.369 & 0.0019 & 1.903 & 0.0018 \\
\hline 8 & 0.386 & 0.1722 & 0.284 & 0.0017 & 1.770 & 0.0081 \\
\hline 9 & 2.415 & 2.6050 & 0.349 & 0.0006 & 1.890 & 0.0009 \\
\hline 10 & 0.197 & 0.3648 & 0.300 & 0.0006 & 1.827 & 0.0011 \\
\hline 11 & 0.950 & 0.0222 & 0.233 & 0.0085 & 1.847 & 0.0002 \\
\hline 12 & 0.183 & 0.3819 & 0.379 & 0.0029 & 1.854 & 0.0000 \\
\hline 13 & 0.665 & 0.0185 & 0.287 & 0.0014 & 1.975 & 0.0132 \\
\hline 14 & 1.271 & 0.2209 & 0.398 & 0.0053 & 1.884 & 0.0006 \\
\hline 15 & 0.961 & 0.0256 & 0.311 & 0.0002 & 1.883 & 0.0005 \\
\hline 16 & 3.149 & 5.5131 & 0.356 & 0.0010 & 1.793 & 0.0045 \\
\hline 17 & 0.271 & 0.2809 & 0.372 & 0.0022 & 1.872 & 0.0001 \\
\hline 18 & 0.219 & 0.3387 & 0.432 & 0.0114 & 1.821 & 0.0015 \\
\hline 19 & 0.480 & 0.1030 & 0.335 & 0.0001 & 1.781 & 0.0062 \\
\hline 20 & 0.113 & 0.4733 & 0.367 & 0.0018 & 1.965 & 0.0110 \\
\hline 21 & 0.871 & 0.0049 & 0.287 & 0.0014 & 1.822 & 0.0014 \\
\hline 22 & 2.395 & 2.5408 & 0.267 & 0.0034 & 1.639 & 0.0488 \\
\hline 23 & 0.300 & 0.2510 & 0.375 & 0.0025 & 1.854 & 0.0000 \\
\hline 24 & 0.251 & 0.3025 & 0.221 & 0.0108 & 1.856 & 0.0000 \\
\hline 25 & 0.795 & 0.0000 & 0.274 & 0.0026 & 1.887 & 0.0007 \\
\hline 26 & 1.272 & 0.2218 & 0.381 & 0.0031 & 1.840 & 0.0004 \\
\hline 27 & 0.718 & 0.0069 & 0.220 & 0.0110 & 1.865 & 0.0000 \\
\hline 28 & 0.551 & 0.0625 & 0.311 & 0.0002 & 1.871 & 0.0001 \\
\hline 29 & 1.232 & 0.1858 & 0.346 & 0.0004 & 1.863 & 0.0000 \\
\hline 30 & 0.804 & 0.0000 & 0.291 & 0.0012 & 1.881 & 0.0004 \\
\hline 31 & 3.839 & 9.2294 & 0.214 & 0.0123 & 1.826 & 0.0012 \\
\hline 32 & 0.848 & 0.0022 & 0.347 & 0.0005 & 1.895 & 0.0012 \\
\hline 33 & 0.582 & 0.0480 & 0.279 & 0.0021 & 1.861 & 0.0000 \\
\hline 34 & 0.915 & 0.0130 & 0.250 & 0.0056 & 1.901 & 0.0017 \\
\hline 35 & 0.240 & 0.3147 & 0.333 & 0.0001 & 1.913 & 0.0028 \\
\hline 36 & 0.907 & 0.0112 & 0.368 & 0.0018 & 1.864 & 0.0000 \\
\hline 37 & 0.117 & 0.4679 & 0.397 & 0.0052 & 1.932 & 0.0052 \\
\hline 38 & -0.202 & 1.0060 & 0.308 & 0.0003 & 1.956 & 0.0092 \\
\hline 39 & 0.759 & 0.0018 & 0.386 & 0.0037 & 1.892 & 0.0010 \\
\hline 40 & 0.666 & 0.0182 & 0.267 & 0.0034 & 1.850 & 0.0001 \\
\hline 41 & 0.988 & 0.0350 & 0.552 & 0.0515 & 1.863 & 0.0000 \\
\hline 42 & 1.084 & 0.0801 & 0.338 & 0.0002 & 1.891 & 0.0010 \\
\hline 43 & 1.072 & 0.0734 & 0.274 & 0.0026 & 1.821 & 0.0015 \\
\hline 44 & 0.747 & 0.0029 & 0.379 & 0.0029 & 1.854 & 0.0000 \\
\hline 45 & 0.918 & 0.0137 & 0.371 & 0.0021 & 1.822 & 0.0014 \\
\hline
\end{tabular}




\section{Lampiran 4}

\begin{tabular}{|c|c|c|c|c|c|c|}
\hline $\mathrm{n}$ & Latar & $\left(I_{\text {rata-rata }}-I_{n}\right)^{2}$ & Cuplikan & $\left(I_{\text {rata-rata }}-I_{n}\right)^{2}$ & Standar & $\left(I_{\text {rata-rata }}-I_{n}\right)^{2}$ \\
\hline 46 & 0.597 & 0.0416 & 0.449 & 0.0154 & 1.820 & 0.0016 \\
\hline 47 & 0.655 & 0.0213 & 0.224 & 0.0102 & 1.852 & 0.0001 \\
\hline 48 & 0.996 & 0.0380 & 0.268 & 0.0032 & 1.815 & 0.0020 \\
\hline 49 & 0.445 & 0.1267 & 0.318 & 0.0000 & 1.910 & 0.0025 \\
\hline 50 & 0.152 & 0.4212 & 0.339 & 0.0002 & 1.905 & 0.0020 \\
\hline 51 & 0.272 & 0.2798 & 0.375 & 0.0025 & 1.843 & 0.0003 \\
\hline 52 & 0.104 & 0.4858 & 0.305 & 0.0004 & 1.881 & 0.0004 \\
\hline 53 & 0.603 & 0.0392 & 0.372 & 0.0022 & 1.780 & 0.0064 \\
\hline 54 & 0.453 & 0.1211 & 0.369 & 0.0019 & 1.907 & 0.0022 \\
\hline 55 & 0.206 & 0.3540 & 0.322 & 0.0000 & 1.863 & 0.0000 \\
\hline 56 & 0.606 & 0.0380 & 0.296 & 0.0008 & 1.855 & 0.0000 \\
\hline 57 & 0.765 & 0.0013 & 0.311 & 0.0002 & 1.864 & 0.0000 \\
\hline 58 & 1.325 & 0.2746 & 0.276 & 0.0024 & 1.760 & 0.0100 \\
\hline 59 & 0.754 & 0.0022 & 0.334 & 0.0001 & 1.857 & 0.0000 \\
\hline 60 & 0.424 & 0.1421 & 0.280 & 0.0020 & 1.895 & 0.0012 \\
\hline$I_{\text {rerata }}$ & $\begin{array}{c}0.801 \mathrm{X} \\
10^{-13} \\
\end{array}$ & & $0.325 \times 10^{-}$ & & $1.860 \times 10^{-}$ & \\
\hline \multicolumn{2}{|c|}{$\sum\left(I_{\text {rerata }}-I_{n}\right)^{2}$} & $\begin{array}{c}33.6393 X \\
10^{-13}\end{array}$ & & $0.2296 \times 10^{-11}$ & & $0.1741 \times 10^{-11}$ \\
\hline
\end{tabular}

\begin{tabular}{|c|c|c|c|c|c|c|c|c|}
\hline $\begin{array}{c}\text { Std. Deviasi }= \\
33.6393 / 59 \\
\end{array}$ & $=$ & 0.755 & $0.2296 / 59$ & $=$ & 0.062 & $0.1741 / 59$ & $=$ & 0.054 \\
\hline $\begin{array}{c}\text { Std.Dev } / \sum_{\mathrm{n}}= \\
0.755 / 0.801\end{array}$ & $=$ & 0.942 & $0.062 / 0.325$ & $=$ & 0.192 & $0.054 / 1.860$ & $=$ & 0.029 \\
\hline \multicolumn{9}{|c|}{ Ketidakpastian sumber standar $\quad: 1.0$} \\
\hline \multicolumn{9}{|c|}{$\begin{array}{l}\text { Ketidakpastian Pengukuran } \\
\text { Elektrometer }\end{array}$} \\
\hline \multicolumn{3}{|c|}{ Ketidakpastian Gabungan } & \multicolumn{6}{|c|}{$: \sqrt{(0.942)^{2}+(0.192)^{2}+(0.029)^{2}+(1.0)^{2}+(1.5)^{2}=2.0435}$} \\
\hline \multicolumn{3}{|c|}{ Faktor cakupan untuk 60 data } & \multicolumn{6}{|c|}{2.0} \\
\hline \multicolumn{3}{|c|}{ Ketidakpastian Bentangan } & \multicolumn{3}{|c|}{$: 2.0 \times 2.04249=4.0870$} & \multicolumn{3}{|l|}{$\%$} \\
\hline \multicolumn{3}{|c|}{ Aktivits awal sumber standar } & \multicolumn{2}{|c|}{8.270} & \multicolumn{4}{|l|}{$\mathrm{MBq}$} \\
\hline \multicolumn{3}{|c|}{ Waktu paro } & \multicolumn{2}{|c|}{10950} & \multicolumn{4}{|l|}{ hari } \\
\hline \multicolumn{3}{|l|}{ Waktu peluruhan } & \multicolumn{2}{|c|}{6873} & \multicolumn{4}{|l|}{ hari } \\
\hline \multicolumn{3}{|l|}{ Aktivitas standar } & \multicolumn{2}{|c|}{5.353} & \multicolumn{2}{|c|}{$\mathrm{MBq}$} & & \\
\hline \multicolumn{3}{|l|}{ Aktivitas cuplikan } & \multicolumn{6}{|c|}{$\left(0.325^{*} 10^{2}-0.801\right) /\left(1.86^{*} 10^{2}-0.801\right)=0.9159$} \\
\hline
\end{tabular}

